E3S Web of Conferences 1, 05009 (2013)

DOI: $10.1051 / \mathrm{e} 3$ sconf/20130105009

(C) Owned by the authors, published by EDP Sciences, 2013

\title{
lon-selective electrodes with solid contact for heavy metals determination
}

\author{
C. Wardak ${ }^{1}$ and J. Lenik ${ }^{2}$ \\ ${ }^{1}$ Department of Analytical Chemistry and Instrumental Analysis, Chemical Faculty, M. Curie-Sklodowska University, \\ M. Curie-Sklodowaka Sq. 3, Lublin, Poland, cecylia.wardak@poczta.umcs.lublin.pl \\ ${ }^{2}$ Department of Analytical Chemistry and Instrumental Analysis, Chemical Faculty, M. Curie-Sklodowska University, \\ M. Curie-Sklodowaka Sq. 3, Lublin, Poland, j.lenik@poczta.umcs.lublin.pl
}

\begin{abstract}
Potentiometric properties of ion-selective electrodes with solid contact for lead, cadmium and zinc determination were investigated. The ionic liquids (ILs) alkyl methyl imidazolium chlorides are used as lipophilic ionic additive to the membrane phase and as transducer media. The basic analytical parameters of the studied electrodes, such as the slope characteristic, the detection limit, response time, lifetime, selectivity coefficients against various inorganic cations as well as the dependence of the electrodes potential on $\mathrm{pH}$ were determined. The obtained electrode are characterized by good analytical parameters: theoretical characteristic slope, low detection limit, short response time and very long lifetime. The electrodes was successfully applied to the direct determination of lead, cadmium and zinc ions in waste water samples. The results obtained indicate that the electrodes provide a good alternative for the determination of these heavy metals in real samples.
\end{abstract}

Key words: Ion-selective electrode, solid contact, heavy metals, potentiometry

\section{Introduction}

In the past few years the need for determination of heavy metals has increased because of growing environmental problems. Lead and cadmium are known as highly toxic elements. Toxic effects of lead result from its involvement in interactions with enzymes and nucleic acid, where inhibition of biochemical pathways often constitutes the source of symptomatic physiological aberrations [Pais 1997]. Cadmium causes damage of human organs such as kidneys, liver and lungs as well as high blood pressure and destruction of red blood cells [Borsari 1994]. Zinc is environmentally ubiquitous and essential for life. Human body contains about $2 \mathrm{~g}$ of zinc but its provisional maximum tolerable daily intake is 1 $\mathrm{mg} / \mathrm{kg}$ of body weight. Large doses of this metal can cause fever, chills, gastroenteritis and pulmonary manifestation. Besides zinc can cause anemia, nausea, vomiting, renal failure and internal organs [Sandstead 2007].

Therefore rapid and selective methods of such metals determination are needed. Potentiometric ion selective electrodes (ISEs) are known to offer an excellent low-cost tool for the selective, sensitive and rapid determination of a vast variety of analytes in different fields of application The use of ion-selective electrodes in the analysis and monitoring of environmental, clinical, and industrial ions and gases has been continuously expanding [Bakker 2002, Bakker 2001. De Marco 2007]. Solid internal contact electrodes refer to a type of ISEs in which the internal reference electrode is in direct contact with the electroactive membrane and contains no internal solution [Buck 1994]. These electrodes will have certain advantages over conventional ones, such as the small size, lower cost of production, and ability to operate in high pressure environments where conventional ISEs might be damaged.

\section{Materials and Methods}

Preparation of the electrodes

A clean silver wire was anodized electrochemically for 5 min. in $4 \mathrm{~mol} \mathrm{~L}^{-1} \mathrm{HCl}$ with constant current $5 \mathrm{~V}$ voltage forming an $\mathrm{Ag} / \mathrm{AgCl}$ electrode. Then the electrode was rinsed with water, dried by tissue-paper and covered by the inner membrane phase.

The electrode membrane phase consists of two layers placed in a Teflon holder: the inner layer containing plasticized PVC doped with IL in which the $\mathrm{Ag} / \mathrm{AgCl}$ electrode is placed, and the outer layer 
containing an ionophore apart from the inner layer components. The outer layer is placed on the inner layer and it is contacted with the tested solution. In order to prepare the inner layer membrane components: IL, PVC and membrane solvents were weighed, mixed thoroughly and the mixture was deaerated by means of vacuum oil pump. The Teflon holder was filled with the mixture so that the silver-silver chloride electrode was immersed in it. Then the mixture was gelated by heating at $80{ }^{\circ} \mathrm{C}$ for $30 \mathrm{~min}$. In order to prepare the outer layer, the active substance (ionophore) was dissolved in a plasticizer (the same as the inner layer) with PVC and IL. The mixture was deaerated, placed on the inner layer and gelated at $80{ }^{\circ} \mathrm{C}$ for $10 \mathrm{~min}$. Then the mixture was cooled to room temperature. The electrodes were conditioned before the measurements in appropriate solution. The composition of the studied membranes as well as conditioning solution are given in Table 1 .

$\cdots$

Table 1. Composition of the membrane of studied electrodes and conditioning solutions.

\begin{tabular}{|c|c|c|c|c|c|}
\hline \multirow[b]{2}{*}{ Electrode } & \multicolumn{4}{|c|}{ Membrane composition, \%wt. } & \multirow{2}{*}{$\begin{array}{l}\text { Conditioning solution } \\
\text { composition, } \mathrm{mol} \mathrm{L}^{-1}\end{array}$} \\
\hline & $\begin{array}{l}\text { Ionophore, } \\
\% \text { wt. }\end{array}$ & $\begin{array}{l}\text { PVC, \% } \\
\text { wt. }\end{array}$ & $\begin{array}{l}\text { Plasticizer, } \\
\% \text { wt. }\end{array}$ & $\begin{array}{l}\text { Ionic } \\
\text { liquid, \% wt. }\end{array}$ & \\
\hline $\mathrm{Pb}$-ISE & $\mathrm{Pb}-\mathrm{IV}, 1$ & 33 & $\begin{array}{l}\text { NPOE, } 31.5 \\
\text { BBPA, } 31.5\end{array}$ & $\mathrm{BMImCl}, 3$ & $1 \times 10^{-7} \mathrm{~mol} \mathrm{~L}^{-1} \mathrm{~Pb}\left(\mathrm{NO}_{3}\right)_{2}$ \\
\hline Cd-ISE & Cd-I, 1 & 33 & NPOE, 63 & EMImCl, 3 & $\begin{array}{l}1 \times 10^{-4} \mathrm{~mol} \mathrm{~L}^{-1} \mathrm{Cd}\left(\mathrm{NO}_{3}\right)_{2} \\
+1 \times 10^{-2} \mathrm{~mol} \mathrm{~L}^{-1} \mathrm{NaNO}_{3} \mathrm{Nol}_{3} \\
+1 \times 10^{-3} \quad \mathrm{~mol} \mathrm{~L}^{-1} \\
\mathrm{Na}_{2} \text { EDTA }(\mathrm{pH}+5.0)\end{array}$ \\
\hline Zn-ISE & $\mathrm{Zn}-\mathrm{II}, 5$ & 33 & NPOE,59 & HMImCl, 3 & $1 \times 10^{-5} \mathrm{~mol} \mathrm{~L}^{-1} \mathrm{Zn}\left(\mathrm{NO}_{3}\right)_{2}$ \\
\hline
\end{tabular}

NPOE- 2-nitrophenyl octyl ether, BBPA- bis (1-butylpenthyl) adipate, MImCl -1-ethyl-3- methylimidazolium chloride, BMImCl- 1-butyl-3-methylimidazolium chloride, HMImCl 1-hexyl-3-methylimidazolium chloride

The measurement of the electromotive force (EMF) of the system: ion-selective electrode - reference electrode Orion 90-02 was carried out at room temperature in a solution stirred with a mechanical stirrer by means of potentiometric system consisting of a 16-channel data acquisition system (Lawson Labs. Inc., USA) and IBM PC computer. A multifunction computer meter CX-741 (Zabrze Mikulczyce Poland) and an Orion 81-72 glass electrode were used for $\mathrm{pH}$ measurement. Sequential dilutions of stock solutions were performed using the 700 Dosino and 711 Liquino pump systems (Metrohm, Switzerland).

\section{Results and Discussion}

In order to estimate the analytical usefulness of the studied ion-selective electrodes their analytical parameters were established: limit detection, characteristic slope, linear range, $\mathrm{pH}$ range, response time and life time as well as selectivity coefficients in relation to many potential interfering ions. The obtained results are summarized in Tables 2 and 3.

The result in Tables 2 and 3 indicated that obtained electrodes are characterized by good analytical parameters. Practical usefulness of the studied sensors was shown by its use for determination of lead, cadmium and zinc ions in real various water samples. The analysis was performed by the standard addition technique. The results obtained for waste water samples are summarized in Table 4. As can be seen, the obtained results are comparable with those obtained by the anodic stripping voltammetry (ASV) analysis. Thus the electrodes provide a good alternative for the determination of lead cadmium and zinc in real samples

Table 2. The analytical parameters of studied ion-selective electrodes.

\begin{tabular}{ccccccc}
\hline Electrode & $\begin{array}{c}\text { Slope } \\
\text { (mV/decade) }\end{array}$ & $\begin{array}{c}\text { Detection limit, } \\
\mathrm{mol} \mathrm{L}^{-1}\end{array}$ & $\begin{array}{c}\text { Measuring } \\
\text { Range, mol L }\end{array}$ & pH range & $\begin{array}{c}\text { Response } \\
\text { time, } \mathrm{s}\end{array}$ & $\begin{array}{c}\text { Lifetime, } \\
\text { months }\end{array}$ \\
\hline $\mathrm{Pb}-\mathrm{ISE}$ & 29.8 & $4.3 \times 10^{-9}$ & $1 \times 10^{-8}-1 \times 10^{-1}$ & $3.5-7.4$ & $5-7$ & 4 \\
$\mathrm{Cd}-\mathrm{ISE}$ & 30.3 & $1.4 \times 10^{-9}$ & $1 \times 10^{-8}-1 \times 10^{-1}$ & $3.8-8.0$ & $5-8$ & 6 \\
$\mathrm{Zn}$-ISE & 31.3 & $4.3 \times 10^{-8}$ & $1 \times 10^{-7}-1 \times 10^{-1}$ & $4.0-8.0$ & $5-7$ & 2 \\
\hline
\end{tabular}


Table 3. Selectivity coefficients of studied electrodes.

\begin{tabular}{lccc}
\hline & \multicolumn{3}{c}{$\log \mathrm{K}_{\mathrm{Pb}, \mathrm{Me}}^{\text {pot }}$} \\
\cline { 2 - 4 } $\mathrm{Ion}$ & $\mathrm{Pb}-\mathrm{ISE}$ & $\mathrm{Cd}-\mathrm{ISE}$ & \multicolumn{2}{c}{ Zn-ISE } \\
\cline { 2 - 4 } $\mathrm{Pb}^{2+}$ & 0 & -1.8 & -1.4 \\
$\mathrm{Cd}^{2+}$ & -5.5 & 0 & 0 \\
$\mathrm{Zn}^{2+}$ & -6.5 & -5.0 & -2.8 \\
$\mathrm{Co}^{2+}$ & -6.4 & -6.6 & -2.8 \\
$\mathrm{Ni}^{2+}$ & -6.2 & -5.9 & -3.4 \\
$\mathrm{Ca}^{2+}$ & -6.0 & -6.3 & -3.7 \\
$\mathrm{Ba}^{2+}$ & -6.4 & -5.9 & -3.8 \\
$\mathrm{Mg}^{2+}$ & -5.1 & -6.7 & -3.2 \\
$\mathrm{Sr}^{2+}$ & -6.1 & -5.9 & -3.3 \\
$\mathrm{Li}^{+}$ & -5.3 & -5.5 & -4.4 \\
$\mathrm{~K}^{+}$ & -5.6 & -6.5 & -4.2 \\
$\mathrm{Na}^{+}$ & -5.4 & -6.2 & \\
\hline
\end{tabular}

Table 4. The analytical parameters of studied ion-selective electrodes.

\begin{tabular}{|c|c|c|c|c|}
\hline Ion & Added, $\mathrm{mg} \mathrm{L}^{-1}$ & Found by ISE, $\mathrm{mg} \mathrm{L}^{-1}$ & Recovery & $\begin{array}{l}\text { Found by ASV method, mg } \\
\qquad \mathrm{L}^{-1}\end{array}$ \\
\hline \multirow[t]{6}{*}{$\mathrm{Pb}$} & - & $0.021 \pm 0.003$ & - & 0.022 \\
\hline & 0.041 & $0.064 \pm 0.003$ & 104.8 & 0.063 \\
\hline & 0.104 & $0.123 \pm 0.005$ & 98.1 & 0.126 \\
\hline & 0.166 & $0.186 \pm 0.005$ & 99.4 & 0.187 \\
\hline & 0.207 & $0.229 \pm 0.007$ & 100.5 & 0.227 \\
\hline & 0.414 & $0.434 \pm 0.007$ & 99.8 & 0.434 \\
\hline \multirow[t]{6}{*}{$\mathrm{Cd}$} & - & $0.011 \pm 0.003^{[\mathrm{b}]}$ & - & 0.012 \\
\hline & 0.056 & $0.068 \pm 0,003$ & 101.5 & 0.067 \\
\hline & 0.090 & $0.102 \pm 0,005$ & 103.0 & 0.104 \\
\hline & 0.112 & $0.123 \pm 0.005$ & 100.0 & 0.122 \\
\hline & 0.224 & $0.236 \pm 0.005$ & 100.4 & 0.235 \\
\hline & 0.560 & $0.570 \pm 0.005$ & 99.8 & 0.574 \\
\hline \multirow[t]{4}{*}{$\mathrm{Zn}$} & - & $0,78 \pm 0,02$ & - & 0,74 \\
\hline & 0,33 & $1,14 \pm 0,02$ & 102,7 & 1,11 \\
\hline & 0,65 & $1,46 \pm 0,05$ & 102,9 & 1,40 \\
\hline & 3,25 & $4,06 \pm 0,05$ & 100,7 & 4,01 \\
\hline
\end{tabular}

\section{Conclusion}

A new solid contact electrode concept is proposed. The presented electrodes are characterized by good analytical parameters: low detection limit, wide measuring range, wide $\mathrm{pH}$ range and excellent (Pb-ISE) or satisfactory selectivity. The application of an ionic liquid instead of a conventional lipophilic additive results in a decrease of membrane resistance and short response time. Furthermore. the ionic liquid keeps constant concentration of chloride ions in the membrane phase, which guarantees the potential stability of internal $\mathrm{Ag} / \mathrm{AgCl}$ electrode, which in turn results in a small potential drift of $0.1-0.3 \mathrm{mV}$ per day. The presented electrodes have no internal solution, so they are simple to construct, easy to transport and more convenient in use because they do not have to work in a vertical position and do not need to operate with the internal solution.

\section{References}

Pais I, Jones Jr.JB, The Handbook of Trace Elements, St. Lucie Press, Florida 1997.

Borsari M in Encyclopedia of Inorganic Chemistry 1st ed., (Ed; King RB), Wiley, New York, 1994.

Sandstead HH, Au W Zinc in Nordberg GF, Fowler BA, Nordberg M, Friberg LT(eds.) Handbook on the Toxicology of Metals, 3rd ed. Elservier Inc 2007.

Bakker E, Pretsch E, The new wave of ion-selective electrodes, Anal. Chem. 2002, 72:420A-426A.

Bakker E, Pretsch E, Potentiometry at trace levels, Trends. Anal. Chem.2001, 20: 11-19.

De Marco R, Clarke G, Pejcic B, Ion-selective electrode potentiometry in environmental analysis, Electroanalysis 2007, 19:1987-2001.

Buck R, Lindner E, Recommendations for nomenclature of ion-selective electrodes. Pure \& Applied Chemistry 1994, 66:2527-2536. 